\title{
Residual insulin secretion in insulin dependent diabetes mellitus
}

\author{
S ROGERS AND M SILINK
}

Department of Endocrinology, Royal Alexandra Hospital for Children, Camperdown, Australia

SUMmARY The residual insulin secretory capacity of 244 children with insulin dependent diabetes mellitus was determined by measurement of their 24 hour urinary $C$ peptide excretion. An inverse linear relation was found between the residual $B$ cell secretion and the duration of diabetes. The age at onset of diabetes did not affect the residual B cell function significantly.

The residual insulin secretory capacity of patients with insulin dependent diabetes mellitus can be determined by measurement of their 24 hour urinary $\mathrm{C}$ peptide excretion. This has been shown to be a valid index of integrated $B$ cell function in diabetic patients $^{1-5}$ and is unaffected by the presence of exogenous insulin and insulin antibodies." Most studies of residual insulin secretion in diabetes mellitus have reported plasma $C$ peptide determinations and basal or post-stimulatory measurements, or both. The studies of 24 hour urinary $C$ peptide excretion have either been reported in adults ${ }^{35}$ or in small studies in children. ${ }^{12789}$ We present results of measurements of urinary $C$ peptide in 244 patients attending the Royal Alexandra Hospital for Children over the past five years to determine the effect of duration of diabetes and age at diagnosis on the residual insulin secretory capacity.

\section{Patients and methods}

Twenty four hour urinary $\mathrm{C}$ peptide excretion was determined in 244 children with insulin dependent diabetes mellitus. There were 123 boys and 121 girls aged between 0.2 and 19.3 years (mean 11.3 years). A histogram depicting the age distribution for both boys and girls is shown in Fig. 1. The duration of diabetes ranged from the initial diagnosis up to $17 \cdot 1$ years (mean $4 \cdot 1$ years). Control values were determined in 47 healthy non-diabetic children aged 3.0 to $16 \cdot 2$ years (mean $12 \cdot 1$ years).

Twenty four hour urine samples were collected in plastic containers without preservatives and kept refrigerated during the collection period. They were then stored at $-20^{\circ} \mathrm{C}$ until ready for assay at which time they were centrifuged to remove sediment. The $\mathrm{C}$ peptide immunoreactivity was measured using a double antibody radioimmunoassay kit (either Immunonuclear or Daiichi) for human $\mathrm{C}$ peptide that uses rabbit antiserum prepared against residues 33 to 63 of the human proinsulin molecule. Urine samples were diluted as necessary with the assay buffer. The lower limit of sensitivity of the assay was $0 \cdot 1 \mathrm{pmol} / \mathrm{ml}$. Low, medium, and high urine controls gave intra-assay coefficients of variation of $3.0 \%$, $7 \cdot 3 \%$, and $8.3 \%$ respectively, and interassay coefficients of variation of $6.6 \%, 6.9 \%$, and $12.5 \%$ respectively. Creatinine concentrations were determined in the urine specimens by the alkaline picrate method. ${ }^{10}$

\section{Results}

The relation between urinary $\mathrm{C}$ peptide excretion and duration of diabetes in the 244 patients is shown in Fig. 2. During the first year of diabetes, $24 \%$ of patients had $\mathrm{C}$ peptide values within the nondiabetic range of 0.83 to $5.80 \mathrm{pmol} \mathrm{C}$ peptide $/ \mu \mathrm{mol}$ creatinine per day (mean (SD) $2.07(1.08)$ ). The mean $C$ peptide excretion for each yearly interval from 0 to 10 years' duration of diabetes was calculated and an inverse linear correlation between the residual $\mathrm{B}$ cell function and duration of diabetes was found. The regression line is defined by the equation $y=-8 \cdot 52+(6 \cdot 04) \quad 1 / x$ with a correlation coefficient $\mathrm{r}$ equal to $0 \cdot 86$, a highly significant correlation $(\mathrm{P}<0 \cdot 001)$. A urinary $\mathrm{C}$ peptide value of $0.2 \mathrm{pmol} C$ peptide $/ \mu \mathrm{mol}$ creatinine per day, which is approximately $10 \%$ of the non-diabetic mean value, was considered to be an inadequate (as exogenous insulin is necessary) but significantly measurable amount. This cut off value was also used by Crossley et al. ${ }^{7}$ The percentage of patients at varying duration of diabetes who had urinary 


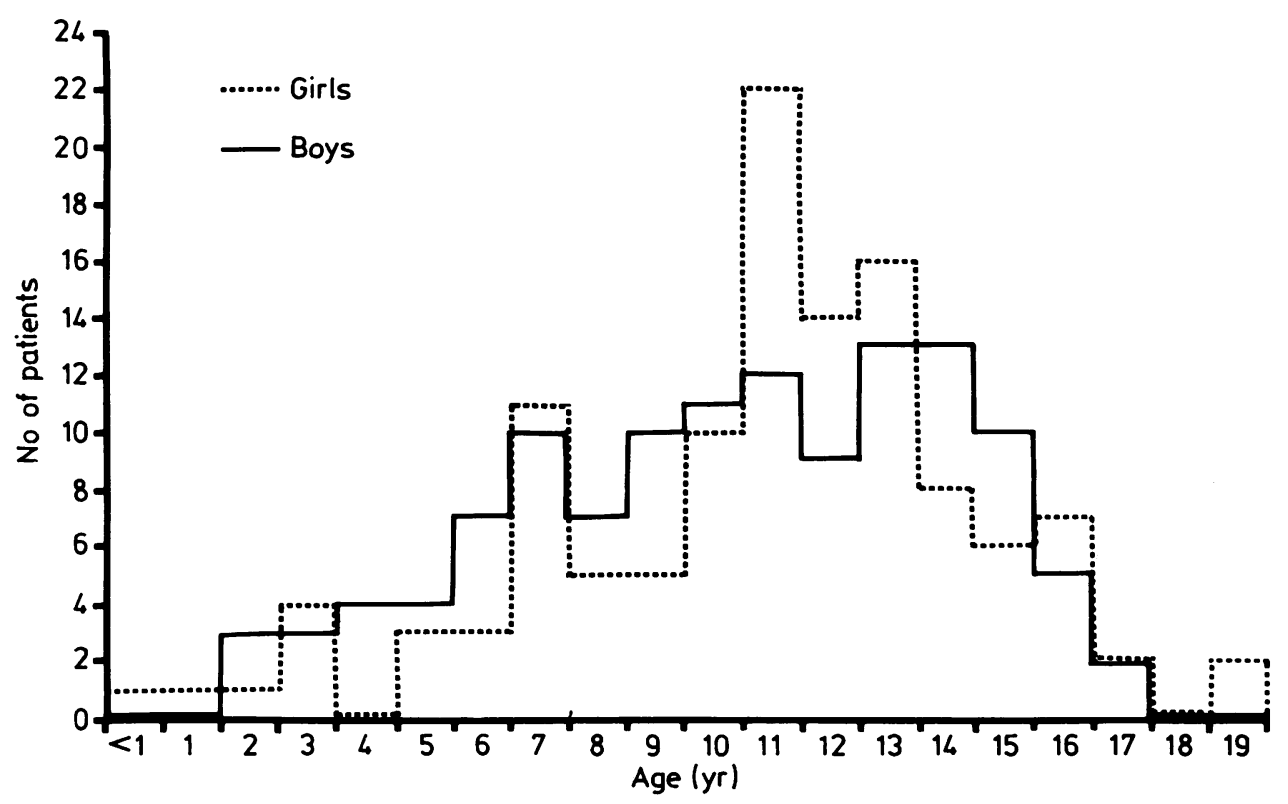

Fig. 1 Age distribution of diabetic patients.

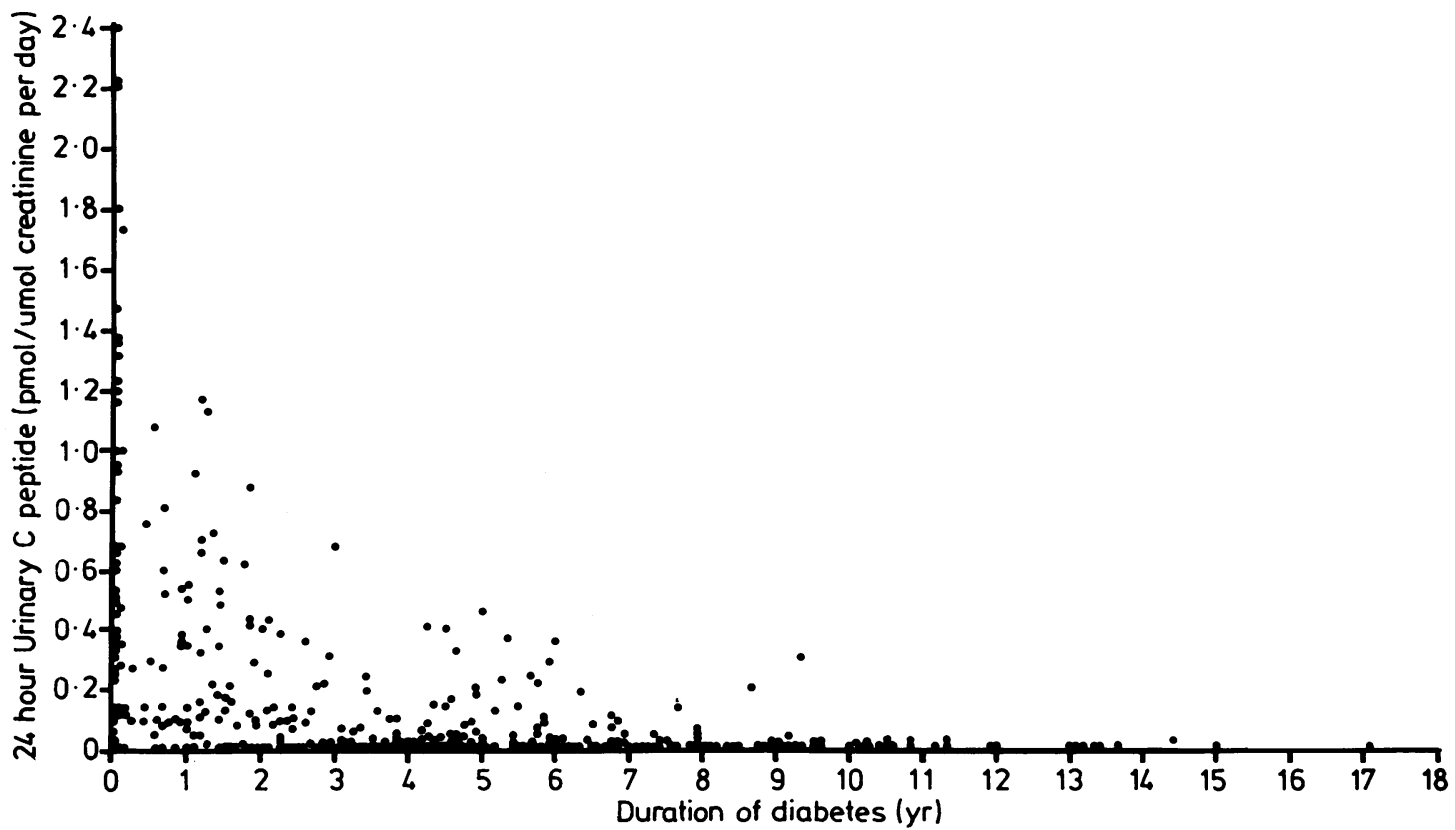

Fig. 2 Twenty four hour urinary C peptide values for the 244 patients investigated plotted against duration of disease. 


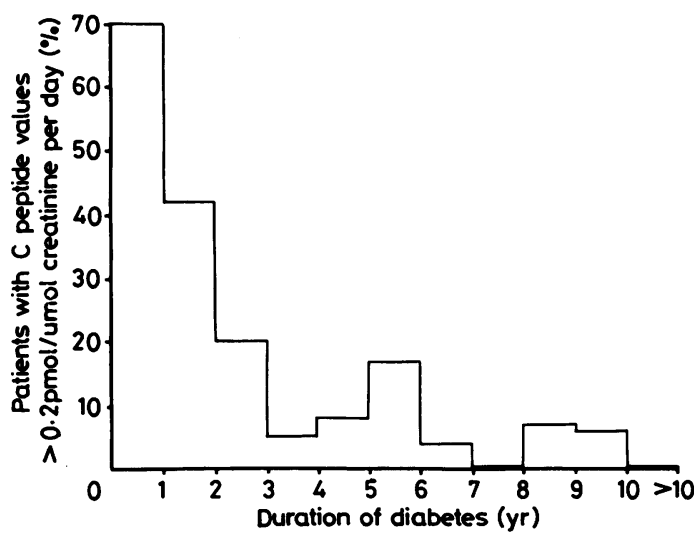

Fig. 3 Percentage of patients with 24 hour urinary $C$ peptide values greater than $0.2 \mathrm{pmol} / \mu \mathrm{mol}$ creatinine per day in relation to disease duration.

C peptide values greater than or equal to $0 \cdot 2$ pmol C peptide/ $\mu \mathrm{mol}$ creatinine per day is given in Fig. 3. During the first three years there is a noticeable decrease in the number of patients with urinary $C$ peptide excretion above this value falling to a very low percentage after six years.

The relation between $B$ cell secretion after diagnosis and the age of the patient at the onset of diabetes was investigated. A multiple regression analysis of the urinary $\mathrm{C}$ peptide excretion, age at onset of diabetes, and the duration of diabetes showed that the age at onset did not have an effect at the 0.20 significance level.

\section{Discussion}

We have found that 24 hour urinary $\mathrm{C}$ peptide determinations are a convenient and non-invasive measure of residual insulin secretory capacity and because of this are useful to monitor changes in $B$ cell activity during the course of insulin dependent diabetes mellitus. They are particularly useful in childhood diabetes where there is considerable patient resistance to repeated blood sampling. It is also possible for the urine samples to be collected at home and kept frozen until they can be brought in at the next visit to the doctor. The assay becomes limited in its usefulness only if and when the diabetic patient develops glomerular filtration problems leading to renal failure. As with previous workers, ${ }^{274}$ we have found that the urinary $C$ peptide value is best expressed in relation to creatinine. The absolute amount of $\mathrm{C}$ peptide excreted per day may be of interest, but as it correlates with body weight ${ }^{3}$ it is of limited use for studying a group of children of varying age and size.
A significant correlation was found between the mean urinary $C$ peptide excretion and the duration of diabetes, although there was a large scatter of urinary $\mathrm{C}$ peptide values in the first two years, as seen in Fig. 2. This makes it impossible to use this correlation as a predictor of residual B cell function for an individual, but shows clearly the trend for the diabetic population. The urinary $\mathrm{C}$ peptide value measured during the first year of diabetes mellitus reflected a substantial insulin secretory capacity in most patients studied, with values within the normal range not uncommon. A significant urinary $C$ peptide value (greater or equal to $0.2 \mathrm{pmol} / \mu \mathrm{mol}$ creatinine per day) was found in $70 \%$ of patients in the first year, $42 \%$ in the second year, and $20 \%$ in the third year. In the first five years of diabetes mellitus significant B cell secretion as thus defined was found in approximately $35 \%$ of patients. In comparison Madsbad ${ }^{11}$ reported that almost $100 \%$ of patients aged 10 to 19.9 years had residual B cell function during the first two years, over $50 \%$ in the first five years, and about $15 \%$ after 10 years' duration. Madsbad's study considered residual B cell function present when post stimulatory plasma $C$ peptide values were equal to or exceeded the effective detection limit of the assay, which was $0.06 \mathrm{pmol} / \mathrm{ml}$. Crossley et $\mathrm{al}^{7}$ reported a much lower incidence of residual B cell function with $66 \%$ of patients having a urinary $\mathrm{C}$ peptide excretion less than $0.20 \mathrm{pmol} / \mu \mathrm{mol}$ creatinine per day during the 12 months after diagnosis.

We were unable to show that the age of the patient at onset of diabetes had a significant effect at the $\mathbf{P}=0 \cdot 20$ level on the residual $\mathrm{B}$ cell secretion after diagnosis. In contrast Crossley et $\mathrm{ll}^{7}$ reported a significant correlation between age at onset and the urinary $C$ peptide value at both one year and two years after diagnosis in 25 children investigated. Other investigators measuring serum immunoreactive $C$ peptide had reported the higher prevalence of residual $B$ cell function in patients diagnosed at a later age than those with early onset diabetes mellitus. ${ }^{11-13}$ Madsbad et al ${ }^{11}$ compared patients diagnosed between 10 and 19.9 years and 30 and 39.9 years and found a higher prevalence of residual $B$ cell secretion in the later onset group when comparing patients of similar duration of disease up to 15 years. From our own studies we are unable to conclude that the age of onset of diabetes influences the residual insulin secretory capacity of B cells, though it may well have a subtle influence which is only evident when comparing patients with a disease onset greater than 10 years apart.

This project was supported by donations from Mr R Williams and 
Mr C E Heath Group of Companies. We thank Mrs A Russell for her assistance.

\section{References}

1 Rappaport EB, Ulstrom RA, Etzwiler DD, Fife D, Hedlund BE, Steffes MW. Urine C-peptide, B-cell function, and insulin requirement. Am J Dis Child 1980;134:1129-33.

2 Aurbach-Klipper J, Sharph-Dor R, Heding LG, Karp M, Laron Z. Residual B cell function in diabetic children as determined by urinary C-peptide. Diabetologia 1983;24:88-90.

${ }^{3}$ Hoogwerf BJ, Goetz FC. Urinary C-peptide: a simple method of integrated insulin production with emphasis on the effects of body, size, diet, and corticosteroids. J Clin Endocrinol Metab 1983;56:60-7.

${ }^{4}$ Kuzuya T, Matsuda A, Sakamoto Y, Tanabshi S, Kajinuma H. C-peptide immunoreactivity (CPR) in urine. Diabetes 1978;27 (Suppl 1):210-15.

5 Horowitz DL, Rubenstein AH, Katz AI. Quantitation of human pancreatic beta-cell function by immunoassay of C-peptide in urine. Diabetes 1977;26:30-5.

${ }^{6}$ Sperling MA. Insulin biosynthesis and C-peptide-practical applications from basic research. Am J Dis Child 1980; 134:1119-21.

7 Crossley JR, James AG, Elliott RB, Berryman CC, Edgar BW.
Residual B-cell function and islet cell antibodies in diabetic children. Pediatr Res 1981;15:62-5.

${ }^{8}$ Elliot RB, Crossley JR, Berryman CC, James AG. Partial preservation of pancreatic $\mathrm{B}$-cell function in children with diabetes. Lancet 1981;ii:1-4.

${ }^{9}$ Mirouze J, Selam L, Pham TC, Mendoza E, Orsetti A. Sustained insulin-induced remissions of juvenile diabetes by means of an external artificial pancreas. Diabetologia 1978;14:223-7.

10 Bonsnes RW, Taussky HH. On the colorimetric determination of creatinine by the Jaffe reaction. J Biol Chem 1945;158: 581-91.

"Madsbad S, Faber OK, Binder C, McNair P, Christiansen C, Transbol I. Prevalence of residual beta-cell function in insulindependent diabetics in relation to age at onset and duration of diabetes. Diabetes 1978;27 (Suppl 1):262-4.

12 Ludvigsson J, Heding LG. C-peptide in children with juvenile diabetes. Diabetologia 1976;12:627-30.

13 Eff C, Faber O, Deckert T. Persistent insulin secretion, assessed by plasma $C$-peptide estimation in long term juvenile diabetes with a low insulin requirement. Diabetologia 1978;15:169-72.

Correspondence to Mrs S Rogers, Department of Endocrinology, Royal Alexandra Hospital for Children, Bridge Road, Camperdown, N.S.W. 2050, Australia.

Received 3 December 1984 